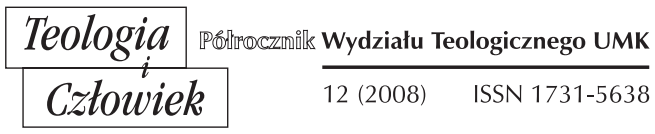

KS. CZESŁAW KRAKOWIAK*

LUBLIN

\title{
KATOLICKI POGRZEB PO KREMACJI
}

Do końca XVIII w. w świecie chrześcijańskim zwyczajną formą było grzebanie ciał zmarłych w ziemi. Dopiero od Rewolucji Francuskiej, a następnie pod koniec XIX w. pod wpływem masonerii i religii wschodnich zaczęły powstawać w Europie "Towarzystwa Kremacji” mające na celu promowanie palenia zmarłych. Uzasadniano to racjami ekonomicznymi, higienicznymi i ekologicznymi. W świecie współczesnym prawodawstwo świeckie nie tylko dopuszcza, ale nawet preferuje kremację ciał zmarłych i składanie ich prochów w urnach (w tzw. kolumbarium) lub zakopywanie w ziemi na cmentarzach, często bez nagrobków. Cmentarze takie przypominają dobrze utrzymane trawniki (np. w USA). Zupełnie nową praktyką jest rozsypywanie prochów w wyznaczonych do tego miejscach, a nawet przechowywanie urn z prochami przez rodziny zmarłych $\mathrm{w}$ mieszkaniach ${ }^{1}$. W konsekwencji następuje zerwanie $\mathrm{z}$ tradycją chrześcijańską, zanikają cmentarze jako ważne miejsca pamięci i modlitwy za zmarłych. Praktyka taka może doprowadzić do braku szacunku do zmarłych, który potwierdza cała historia ludzkości. W połowie XX w. zmieniły się rów-

* Ks. dr hab. Czesław Krakowiak, prof. KUL, Wydział Teologii KUL, kierownik Katedry Teologii Liturgii w Instytucie Teologii Pastoralnej.

${ }^{1}$ Zob. G. Muzzi, La cremazione e la dispersione delle ceneri, Civiltà Cattolica 152, 2001, nr 3635, s. 473-480; F. Di Molfetta, Inumazione e cremazione. Tradizione cristiana, ritualitŕ, legislazione, Rivista Liturgica 93, 2006, s. 747-753. 
nież przepisy prawa kościelnego dotyczące grzebania zmarłych². Powstają więc pytania, jak w świetle Bożego Objawienia, tradycji Kościoła i wiary chrześcijańskiej należy ocenić te nowe zjawiska? Czy coraz bardziej rozpowszechniająca się praktyka kremacji, a następnie sposób postępowania z prochami zmarłych nie doprowadzą także wśród chrześcijan do zaniku tradycyjnych cmentarzy, a $\mathrm{w}$ rezultacie pamięci i modlitwy za zmarłych, które mają podstawę w wierze w zmartwychwstanie? Czy obecnie obwiązujące obrzędy pogrzebowe Kościoła katolickiego dostosowane są do pogrzebu ciał poddanych kremacji?

\section{GODNOŚĆ I SZACUNEK NALEŻNE LUDZKIEMU ClAŁU W ŚWIETLE BIBLII}

W odróżnieniu od poglądów starożytnych filozofów, według biblijnej koncepcji człowieka stworzonego na obraz i podobieństwo Boże ciało i dusza tworzą jedność. Ciało człowieka nie jest więzieniem dla duszy, chociaż umiera i niszczeje, to przecież kiedyś zmartwychwstanie (por. 1 Kor 15,35). W świetle Tajemnicy Wcielania Syna Bożego ciało człowieka nabiera jeszcze większej wartości i godności. Od dnia wszczepienia Chrystusa przez sakrament chrztu człowiek jako osoba cielesno-duchowa staje się świątynią Ducha Świętego (por. 1 Kor 3,16-17). Dlatego chrześcijanie odnoszą się z szacunkiem dla ludzkiego ciała zarówno w czasie ziemskiego życia człowieka, jak i po jego śmierci, zachowując w tym względzie tradycję ludu Bożego Starego Testamentu. Wyrazem tego jest ze czcią i szacunkiem grzebanie ciała zmarłych w ziemi zarówno przez żydów, jak i przez chrześcijan. Chociaż w Palestynie znana była kremacja, to jednak żydzi bardzo starannie grzebali ciała swoich zmarłych. Szacunek dla ciała wyrażał się ponadto w szybkim jego pogrzebaniu (tego samego dnia). Żydzi nie znali balsamowania ciał zmarłych praktykowanego w Egipcie (por. Rdz 50,2-3.26) . $^{3}$

Chociaż w Starym Testamencie nie ma wyraźnego zakazu palenia ciał zmarłych, to tego rodzaju praktyka pojawiała się jedynie wyjątkowo i dotyczyła zawsze tych osób, dla których spalenie ciała było dodatkową karą za popełnione

${ }^{2}$ Zob. E. Górecki, Kremacja w Kościele katolickim, EK IX 1260; E. Sakowicz, Kremacja w religiach niechrześcijańskich, EK IX 1259; J. Kujawski, Przepisy kościelne w sprawie kremacji zmartych, Homo Dei 74, 1975, nr 1, s. 59-66; Z. Suchecki, La cremazione nel diritto canonico e civile, Libreria Editrice vaticana, Città del Vaticano 1995; R. Groń, Kościót wobec kremacji zwotok ludzkich, Wrocławski Przegląd Teologiczny 8, 2000, nr 2, s. 99-114; G. Zanchi, Il misterioso destino dei corpi. Storia della prassi funerali in Occidente, Rivista del clero italiano 84, 2003, s. 273-278; J. Gręźlikowski, Kremacja zwłok zmartych w świetle przepisów prawa kanonicznego, w: Prawo pogrzebowe, red. J. Gręźlikowski, Kutno 2005, s. 41-54; F. Di Molfetta, Inumazione e cremazione, s. 739-746; T. Chałupczak, Obrzędy chrześcijańskiego pogrzebu a kremacja, Współczesna Ambona 35, 2007, nr 3, s. 190-200.

${ }^{3}$ Według wierzeń egipskich pobyt pod ziemią trwa tak długo, jak długo pozostaje tam ciało (stąd balsamowanie). 
grzechy (por. Rdz 38,24; Kpł 20,14; 21,9; Am 2,1), podobnie jak niepogrzebanie ciała. Kremację stosowano wobec przestępców i wrogów, aby ich ostatecznie zniszczyć. Inne wzmianki o paleniu zwłok odnoszą się do czasu wojny lub zarazy (por. Kpł 13,1-59; 2 Krn 16,12-14; 21,18-19). Znana jest tylko kremacja Saula i jego synów (1 Sm 31,12-13)4. Żydzi bowiem uważali kremację ciał zmarłych za niezgodną $\mathrm{z}$ należnym im szacunkiem.

W starożytnym świecie greckim i rzymskim obowiązywała zasada niepozostawiania zwłok bez pogrzebu, z którym związane były różne obrzędy: pochowanie ciała na cmentarzu lub spalenie. Kremacja ciała związana była z przekonaniem, że ogień oczyszcza duszę i uwalnia z ciała, czyniąc ją niezniszczalną. Grecy wierzyli, że miejsca pochówku zmarłych pozostają pod opieką bóstwa podziemi Charona, który przeprowadza ich do Hadesu.

Chrześcijanie, podobnie jak żydzi, mieli wielki szacunek dla ludzkiego ciała. Kościół zabraniał palenia ciał zmarłych, bazując na nauce o nieśmiertelności duszy i o zmartwychwstaniu. Miało to związek również z koncepcją życia i śmierci, także $\mathrm{w}$ duchu Bożego Objawienia. W chwili śmierci ustaje zewnętrzna aktywność człowieka. Duch (nefesz) oddala się od ciała, ale zmarły przebywa $\mathrm{w}$ szeolu, $\mathrm{w}$ królestwie zmarłych, $\mathrm{w}$ oczekiwaniu na ponowne powstanie do życia. Dlatego śmierć podobna jest do snu, a brak pogrzebu jest karą (por. Pwt 21,23). Pogrzeb wyraża także ból żyjących po stracie bliskich (por. $2 \mathrm{Sm} \mathrm{3,31;} \mathrm{Jr} \mathrm{16,6).} \mathrm{W} \mathrm{tradycji} \mathrm{chrześcijańskiej} \mathrm{śmierć} \mathrm{i} \mathrm{pogrzeb} \mathrm{-} \mathrm{składa-}$ nie ciała do ziemi, nie jest całkowitym unicestwieniem ludzkiej egzystencji, ale dopełnieniem życia, które odnajduje swoje pełne znaczenie w śmierci Chrystusa. Chrześcijanin jest jak ziarno, które dopiero wtedy wyda owoc, gdy zostanie zakopane w ziemi (por. J 12,24). Chrześcijanie uważali kremację za pogański i niehumanitarny zwyczaj, gdyż nie wyrażał on szacunku i miłości okazywanych ciału, które ożywiała nieśmiertelna dusza, i które było świątynią Ducha Świętego. W czasie prześladowań znane były sporadyczne fakty palenia przez pogan ciał męczenników, wynikające z przekonania, że uniemożliwi to ich zmartwychwstanie. Jednak najważniejszym argumentem przeciw kremacji było naśladowanie sposobu pogrzebu Jezusa (por. Mt 27, 57-60; Mk 15,43-46; Łk 23,60-53; J 19,38-42).

\section{NEKROPOLIE I CHRZEŚCIJAŃSKIE CMENTARZE}

Rzymskie prawo tzw. XII Tablic nakazywało zakładanie cmentarzy poza miastem i przewidywało zarówno grzebanie ciał, jak i kremację․ Cmentarz

\footnotetext{
${ }^{4}$ J. Kujawski, Przepisy kościelne w sprawie kremacji, s. 61; Z. Suchecki, La cremazione,
} s. $14-37$.

${ }^{5}$ Z. Suchecki, La cremazione, s. 56-57.

${ }^{6}$ Tamże, s. $45-50$. 
uznawany był za miejsce święte. Chrześcijanie, stosując się do tego prawa, grzebali swych zmarłych poza miastami, w grobach ziemnych. Tertulian († 220) określał kremację jako „najdzikszy zwyczaj” (consuetudo atrocissima). W tradycji chrześcijańskiej obrzędy pogrzebowe, groby i cmentarze mają wielkie znaczenie, nie tylko ze względu na szacunek dla ciała ludzkiego, ale także dla żyjących. Chrześcijanie nie używali nazwy „nekropolia”, czyli miasto zmarłych, lecz "cmentarz" (od łac. coemeterium, gr. koimeterion, czasownik koimao - zasypiać, spać). Już sama nazwa „,cmentarz” wskazuje, że jest on miejscem jedynie czasowego spoczynku zmarłych w oczekiwaniu na zmartwychwstanie (dormitorium) ${ }^{7}$. Potwierdza to m.in. forma modlitwy za zmarłych w Kanonie rzymskim: „Pamiętaj, Boże, o swoich sługach i służebnicach N. i N., którzy przed nami odeszli ze znakiem wiary i śpią w pokoju"s. Śmierć jest jakby snem, z którego wierni powstaną, każdy w swoim czasie (por. 1 Tm 4,13-18).

Chrześcijanie początkowo nie mieli własnych cmentarzy. W II w. grzebali swoich zmarłych na terenach bogatych rodzin lub w katakumbach. Dopiero od III w. można mówić o cmentarzach chrześcijańskich. Gdy cesarz Justynian († 565), kodyfikując prawo rzymskie, zniósł zakaz grzebania zmarłych w obrębie miast, upowszechniał się zwyczaj chowania wiernych wokół kościoła, a od VI w. nawet w samym kościele apud ecclesiam (pod posadzką) $)^{9}$ Dotyczyło to pierwotnie tylko ciał męczenników, później osób zmarłych w opinii świętości, następnie biskupów i cesarzy, a od XII w. praktycznie każdy mógł być pochowany w kościele. Jednak uważano to za przywilej i rezerwowano go jedynie dla osób zasłużonych dla tego kościoła. Dopiero Pius V konstytucją apostolską Cum primum apostolatus (1 IV 1566) ograniczył tę praktykę. Tradycyjnie jednak większość cmentarzy znajdowała się wokół budynku kościelnego. Cmentarze były także miejscem sprawowania liturgii i spotkań rodzinnych oraz przyjaciół przy grobie zmarłego ${ }^{10}$.

\section{STANOWISKO KOŚCIOŁA KATOLICKIEGO WOBEC KREMACJI}

Kremacja była niekiedy praktykowana w krajach chrześcijańskich już we wczesnym średniowieczu, ale w sytuacjach „wyższej konieczności”, np. nagromadzenia dużej liczby zwłok w wyniku wojny, zarazy lub klęski głodu. Zwłoki palono, aby uchronić ludność przed zarazą i uniknąć rozprzestrzeniania

${ }^{7}$ H. Pietras, Początki teologii Kościoła, WAM, Kraków 2007, s. 53; zob. G. Zanchi, Il misterioso destino dei corpi, s. 278-284.

8, , [...] qui nos praecesserunt cum signo fidei, et dormiunt in somno pacis".

${ }^{9} \mathrm{G}$. Zanchi pisze, że w tym czasie "non c'è villaggio senza chiesa; non c'è chiesa senza cimitero". Il misterioso destino dei corpi, s. 285.

${ }^{10}$ Tamże, s. 286. 
się chorób. Karol Wielki († 814) zabraniał kremacji, którą uznawał za obrzęd pogański (ritus paganus) ${ }^{11}$.

Dopiero od Oświecenia także w krajach chrześcijańskich zaczęto popierać kremację, głównie ze względów higienicznych, ale również z powodu głoszonej szczególnie przez masonerię nienawiści do religii ${ }^{12}$. Wtedy Kościół katolicki po raz pierwszy sprzeciwił się tej praktyce w wypowiedzi Kongregacji Świętego Oficjum Quo cadaverum cremationem (19 V 1889). Kościół powołuje się w niej na niezmienną od początku tradycję grzebania zmarłych, poza sytuacjami nadzwyczajnymi. Niezachowanie tego zwyczaju pociągało za sobą ekskomunikę i pozbawienie pogrzebu kościelnego. Według Kongregacji, próba wprowadzenia tych pogańskich obrzędów do chrześcijańskiej kultury ma w rzeczywistości niechrześcijańskie i masońskie motywy. Sprzeciw Kościoła opierał się także na fakcie, że nie było i nie ma żadnego liturgicznego obrzędu dla kremowania zwłok, a ponadto kremacja jest niezgodna z niezmienną tradycją Kościoła katolickiego. Fakt, że Kościół zezwalał na taką praktykę w ściśle określonych sytuacjach (wojny lub epidemie) nie może uzasadniać szerszego jej stosowania. Według Kościoła kremacja stanowi antychrześcijańskie i materialistyczne pojmowanie śmierci oraz przyczynia się do zaniku pamięci i modlitwy za zmarłych.

Codex Iuris Canonici z 1917 r. (can. 1203 § 1) nakazywał grzebanie ciał wiernych zmarłych i potępiał kremację ${ }^{13}$. Polecenie $w$ jakiejkolwiek formie spalenia swojego ciała Kodeks uznawał za niezobowiązujące (tamże § 2). Jedynie bardzo ważne przyczyny mogły usprawiedliwiać odstąpienie od tej zasady, jak np. wojna i/lub zapobieżenie rozprzestrzenieniu się śmiertelnych epidemii. Ci, którzy wyrazili wolę kremacji swoich zwłok, byli pozbawieni chrześcijańskiego pogrzebu (can. $\left.1240 \S 15^{\circ}\right)^{14}$. Kongregacja Świętego Oficjum w instrukcji De crematione cadaverum (19 IV 1926) kremację określiła barbarzyńskim zwyczajem (barbarum hunc morem), deprecjacją ludzkiego ciała i nauczania Kościoła pod pretekstem naukowego postępu i zabroniła katolikom przynależności do „Towarzystw Kremacji”. Ponieważ w pewnych warunkach

${ }^{11}$ "Si quis corpus defuncti hominis secundum ritum paganorum fiamma consumi fecerit, et ossa eius ad cineram redierit, capite punietur". PL 97, 145.

${ }^{12}$ Z. Suchecki, La cremazione, s. 116 i 156-157. Pierwsze krematorium zbudowano w Mediolanie w 1876 r. Umieszczono na nim następujący napis: „Vermibus erepti, puro consummimur igni; Indote vetitum - mens renovata petit”. Tł. pol. „Wyrwani robactwu - niszczejemy w czystym ogniu; Zacofany zakaz - myśl oświecona odrzuca". J. Kujawski, Przepisy kościelne w sprawie kremacji, s. 62. Po roku 1870 powstawały w Italii „Towarzystwa Kremacji” i budowano krematoria, np. w Postoi na frontonie krematorium umieszczono podobny napis: „Nasze ciała nie zostaną wydane na żer robactwa, ale niech spali je czysty ogień bogów". T. Chałupczak, Obrzędy chrześcijańskiego pogrzebu a kremacja, s. 195.

${ }_{13}^{13}$ "Fidelium defunctorum corpora sepelienda sunt, reprobata eorundem creamatione".

14 "Qui mandaverint suum corpus cremationi tradi". J. Kujawski, Przepisy kościelne w sprawie kremacji, s. 62-63; Z. Suchecki, La cremazione, s. 146-151. 
kremacja jest dopuszczalna, sama w sobie nie jest absolutnie zła (non est absolute mala $)^{15}$.

Ważna zmiana w stanowisku Kościoła wobec kremacji nastąpiła po wydaniu przez Święte Oficjum Instrukcji „De cadaverum crematione” Piam et constantem (8 V 1963) ${ }^{16}$. Według niej spalenie ciała nie dotyka duszy człowieka i nie przeszkadza Bożej wszechmocy w jego rekonstrukcji, dlatego nie sprzeciwia się dogmatowi ani wierze chrześcijańskiej. Niemniej, w instrukcji zaleca się tradycyjne grzebanie ciała, a stosowanie kremacji jedynie w wypadkach konieczności. Kto zdecydował się na kremację, przez to samo nie może być pozbawiony sakramentów ani publicznych modlitw Kościoła, jeśli nie wynikało to $\mathrm{z}$ negacji wiary i nienawiści do Kościoła. Instrukcja zaznaczała równocześnie, że obecnie kremacja w zasadzie nie jest wynikiem nienawiści do Kościoła ani do zwyczajów chrześcijańskich, lecz najczęściej stosowana jest z motywów higienicznych, ekonomicznych lub innego rodzaju. Zalecała równocześnie, aby wiernych wychowywać do tego, że Kościół preferuje pogrzebanie zmarłych w ziemi. Odnośnie do obrzędów pogrzebu kościelnego i modlitw zaznaczono, że nie mogą być sprawowane w miejscu kremacji ani nie można towarzyszyć tam ciału zmarłego. Wtedy liturgia pogrzebowa ma odbywać się przed przeniesieniem ciała do krematorium. Jedynie w wypadkach nadzwyczajnych, za zgodą biskupa można ją sprawować przy urnie. Kongregacja wyraźnie zabrania rozsypywania prochów, gdyż wierni winni znać miejsce spoczynku swoich zmarłych.

Zawarta w instrukcji doktryna rzutuje na praktykę pastoralną Kościoła dotyczącą pogrzebu, w której należy zachować następujące zasady: tradycyjne grzebanie zmarłych: kremacja jest dopuszczalna jedynie w wypadkach prawdziwej konieczności; nie jest ona zakazana ze swej istoty, a tylko wtedy, gdy neguje prawdy chrześcijańskiej wiary lub wynika z nienawiści do Kościoła; z samego wyboru kremacji nie wynika, że osoby te pozbawione są sakramentów i publicznych modlitw za zmarłych; z faktu, że Kościół preferuje tradycyjne grzebanie zmarłych i racji wychowawczych obrzędy pogrzebowe nie mogą odbywać się tam, gdzie dokonuje się kremacja.

${ }^{15}$ AAS 18, 1926, s. 282-283.

${ }^{16}$ AAS 56, 1964, s. 822-823. J. Kujawski, Przepisy kościelne w sprawie kremacji, s. 64; Z. Suchecki, La cremazione, s. 167-179. Wspólnoty protestanckie zaakceptowały kremację znacznie wcześniej niż katolicyzm, ale nie zawsze jednomyślnie. Pierwsze krematoria w krajach protestanckich powstały pod koniec XIX w. Obecnie większość Kościołów protestanckich akceptuje kremację i nawet rozsypywanie prochów w specjalnych „ogrodach pamięci”. Zob. E. Genre, Morte e sepolture nella cultura e spiritualità protestante, Rivista Liturgica 93, 2006, s. 718-734. Prawosławie stanowczo zakazuje kremacji (którą uważa za brak wiary w zmartwychwstanie), ale dopuszcza wyjątki od tej reguły, np. zarządzenie władz państwowych lub masowa epidemia. Nie odprawia się żadnych obrzędów religijnych nad spopielonymi zwłokami. 
Dalsza zmiana stanowiska Kościoła w stosunku do kremacji nastąpiła wraz z wydaniem Ordo Exsequiarum w 1969 r.: „Tym, którzy wybrali spalenie swoich zwłok, należy udzielić pogrzebu chrześcijańskiego, chyba że na pewno wiadomo, iż podjęli oni tę decyzję z motywów przeciwnych zasadom wiary chrześcijańskiej. Obrzędy pogrzebowe należy odprawić w formie przyjętej w danym kraju, tak jednak, by było wiadomo, że Kościół wyżej ceni zwyczaj grzebania zwłok, ponieważ sam Chrystus chciał być pogrzebany. Należy również unikać niebezpieczeństwa zgorszenia lub zdziwienia ze strony wiernych. Obrzędy, które odbywają się w kaplicy lub przy grobie, w tym wypadku mogą być odprawiane $\mathrm{w}$ budynku krematorium, a nawet $\mathrm{w}$ samej sali krematorium, jeżeli nie ma innego odpowiedniego miejsca. Roztropnie jednak należy zapobiec niebezpieczeństwu zgorszenia lub indyferentyzmu religijnego. Gdy z zagranicy przesyła się urnę z prochami zmarłego, można odprawić pogrzeb według pierwszej formy, rozpoczynając od Mszy pogrzebowej, albo według formy drugiej" (nr 15) ${ }^{17}$.

Podane w Ordo Exsequiarum zasady dotyczące kremacji w 1977 r. doprecyzowała Kongregacja Kultu Bożego i Dyscypliny Sakramentów, odpowiadając na pytanie o możliwość celebracji pogrzebu w kościele przy urnie. Według Kongregacji: „Nie wydaje się właściwe, aby nad prochami celebrować obrzędy, które odpowiadają czci ciału. Nie chodzi o potępienie kremacji, ale o zachowanie prawdziwości znaku i akcji liturgicznej. W rzeczywistości prochy, które oznaczają i wyrażają zniszczenie ciała ludzkiego, ukrywają »sen « w oczekiwaniu na zmartwychwstanie. Poza tym ciało (a nie prochy) otrzymuje cześć liturgiczną, ponieważ od chrztu stało się świątynią Ducha Świętego" ${ }^{\prime 18}$. Spopielone ciało nie wyraża tak dobrze jak zwłoki liturgicznego bogactwa pogrzebu, który podkreśla jego paschalny charakter i wiarę w zmartwychwstanie ciał.

Według Kodeksu Prawa Kanonicznego z 1983 r. wierni zmarli powinni otrzymać pogrzeb kościelny zgodnie z normami prawa (kan. 1176 § 1) i z zachowaniem przepisów liturgicznych (§ 2). Pogrzeb ma na celu wypraszanie duchowej pomocy zmarłym, jest wyrazem szacunku dla ludzkiego ciała, a żyjącym niesie pociechę nadziei (tamże). „Kościół usilnie zaleca (enixe commendat) zachowanie pobożnego zwyczaju grzebania ciał zmarłych. Nie zabrania jednak kremacji, jeśli nie została wybrana z pobudek przeciwnych nauce chrześcijańskiej” (§ 3). Dlatego pogrzeb kościelny nie przysługuje tym, którzy „wybrali spalenie swojego ciała z motywów przeciwnych wierze chrześcijańskiej” (kan. 1184 § $12^{\circ}$ ).

${ }_{17}$ Zob. L. Brandolini, Il nuovo „Ordo Exsequiarum”, Ephemerides Liturgicae 84, 1970, s. 129-148; S. Człapa, Wartości duszpasterskie nowych obrzędów pogrzebu, Homo Dei 48, 1979, s. 31-35; A. Carrara, Per una buona celebrazione del rito delle esequie, Rivista del clero italiano 84, 2003, s. 21-41; J. Kujawski, Przepisy kościelne w sprawie kremacji, s. 65-66; Z. Suchecki, La cremazione, s. 181-184.

${ }^{18}$ Notitiae 13, 1977, s. 45. 
Kodeks naucza również, że odmówienie pogrzebu kościelnego pociąga za sobą także odmowę ,jakiejkolwiek Mszy pogrzebowej" (kan. 1185) ${ }^{19}$.

W Katechizmie Kościoła Katolickiego zostały w zasadzie powtórzone wcześniejsze wskazania Kościoła odnośnie do pogrzebu, z podkreśleniem paschalnego charakteru śmierci chrześcijanina (nr 1685). Katechizm podkreśla, że „ciała zmarłych powinny być traktowane z szacunkiem i miłością wypływającą z wiary i nadziei zmartwychwstania". Przypomina również, że grzebanie zmarłych jest „uczynkiem miłosierdzia względem ciała” i „uczczeniem dzieci Bożych będących świątynią Ducha Świętego" (nr 2300). Odwołując się do KPK kan. 1176 § 3, potwierdza, że „Kościół zezwala na kremację zwłok, jeśli nie jest ona przejawem podważania wiary w zmartwychwstanie ciała" (nr 2301). W Katechizmie na uwagę zasługuje brak przypomnienia i polecenia zachowania tradycyjnego zwyczaju Kościoła grzebania ciał zmarłych. Katechizm, odwołując się do rytuału, Obrzędy pogrzebu przypomina, że w czasie pogrzebu Kościół żegna zmarłego, poleca go Bogu i jest to „ostatnie pożegnanie, jakie wspólnota chrześcijańska oddaje swemu członkowi, zanim ciało będzie wyniesione i pogrzebane" (nr 1690) ${ }^{20}$. W świetle przywołanych tekstów ze zwyczajnego nauczania Kościoła nie można uważać, że uznaje on kremację ciała na równi z tradycyjnym grzebaniem zmarłych.

Współcześnie, ze względu na zmienione warunki przestrzeni i życia, coraz powszechniej przyjmuje się praktyka kremacji ciał zmarłych. Jest ona dozwolona także dla wiernych Kościoła katolickiego. Jednak konsekwencją kremacji może być zanikanie tradycyjnych cmentarzy jako miejsca czasowego spoczynku zmarłych, ale także zwyczajnych grobów, przy których wierni zanoszą do Boga modlitwy za zmarłych. Ponadto poddanie zmarłego kremacji jest wyrazem przedmiotowego traktowania jego ciała. Nierzadko obecnie pociaga za sobą pewne nieznane dotąd praktyki, które nie są akceptowane przez Kościół, takie jak rozsypywanie prochów w określonych miejscach (tzw. „ogrody pamięci") lub przechowywanie ich w urnie w domu ${ }^{21}$. Na ten problem zwraca uwagę Dyrektorium o pobożności ludowej i liturgii, które zaleca unikanie „mumifikacji, balsamowania czy kremacji"22. Działania takie mogą czasem wynikać z pojmowania śmierci jako stanu całkowitego zniszczenia ciała człowieka.

${ }^{19}$ Zob. Z. Suchecki, La cremazione, s. 196-202.

${ }^{20}$ Por. Obrzędy pogrzebu, nr 56. Według Kompendium Katechizmu Kościoła katolickiego, nr 479 „Ciała zmarłych powinny być traktowane z szacunkiem i miłością. Dozwolona jest kremacja zwłok, jeśli nie jest ona przejawem podważania wiary w zmartwychwstanie ciała".

${ }^{21}$ F. Di Molfetta, Inumazione o cremazione, s. 747-752; G. Muzzi, La cremazione e la dispersione delle ceneri, s. 475-476; J. Salij, Kremacja i „ogrody pamięci”, W Drodze 2006, nr 11, s. 93-98.

${ }^{22}$ Kongregacja ds. Kultu Bożego i Sakramentów, Dyrektorium o pobożności ludowej i liturgii. Zasady i wskazania, Pallottinum, Poznań 2003, nr 254. 
Dlatego w pobożności chrześcijańskiej zwyczajnym sposobem pogrzebu wiernego jest zakopanie jego ciała w ziemi. Jeśli stosuje się kremację, Dyrektorium zaleca, aby wtedy „zachęcić wiernych, by nie przechowywali w domu prochów zmarłych, lecz dokonali ich pogrzebania aż do dnia, gdy Bóg wskrzesi z prochu ziemi tych, którzy w niej spoczywają, a morze odda swoich zmarłych (por. Ap 20, 13)"23. Ostrzeżenie Kościoła w tym względzie jest jak najbardziej uzasadnione, gdyż prochy zmarłych mogą być używane do celów zabobonnych, niekiedy prowadzą do tworzenia z nich syntetycznych kamieni używanych następnie jako biżuteria ${ }^{24}$.

Na uwagę zasługuje ocena praktyki kremacji teologa i liturgisty protestanckiego J. J. von Allmena, który podkreśla, że według tradycji chrześcijańskiej ciał wiernych zmarłych nie poddaje się spaleniu, lecz zakopuje się w ziemi ${ }^{25}$. W odstąpieniu przez Kościół katolicki od tej tradycji i jego zgodzie na kremację widzi on zwycięstwo doktryny dualistycznej antropologii, według której w ogniu może być wyzwolona dusza ze skorupy ciała, w którym była uwięziona. Widzi w tej praktyce również wpływ religii Wschodu na zachodnie chrześcijaństwo oraz wskrzeszenie antycznej religii Grecji ${ }^{26}$.

\section{JAKIE OBRZĘDY POGRZEBOWE PO KREMACJI}

Wydany już prawie 40 lat temu rytuał Kościoła katolickiego Ordo Exsequiarum nie zawiera obrzędów pogrzebowych wtedy, gdy nastąpiła kremacja ciała i prochy zmarłego znajdują się w urnie. Nie ma także specjalnych obrzędów pogrzebu ciała, które ma być dopiero spalone. Kongregacja Kultu Bożego jak dotąd nie opracowała jeszcze takiego rytuału. Prace nad nimi jeszcze trwają ${ }^{27}$. Obrzędy i teksty obecnego rytuału, poza wzmianką, że dopuszczalna jest także

${ }^{23}$ Tamże.

${ }^{24}$ Zob. E. Romańska, Biżuteria ze zwtok. Z prochu powstałeś, w diament się obrócisz, „Wprost" z 28 III 2004, s. 82.

25, ,.... [a cristiana traditio è quella seppellire e non di incenerire i cadaveri dei credenti". Prophétisme sacramental, Neuchâtel 1964, s. 228. E. Genre podaje charakterystyczne napisy umieszczone na krematoriach w Verese i Zurychu: „Hactenus adstricti terrae ascendamus ad aeter” i „Flamme, löse das Vergnagenheit befreit ist das Unsterbliche”. Morte e sepoltura nella cultura e spiritualità protestante, s. 727.

${ }^{26}$, ,...] risuscitare la religione dell'antica Grecia". E. Genere, Morte e sepolture nella cultura e spiritualità protestante, s. 732 .

${ }^{27} \mathrm{Na}$ spotkaniu biskupów Panamy w Kongregacji Kultu Bożego 21 III 1994 poinformowano, że w przygotowaniu jest editio typica altera "Ordo Exsequiarum”. "Notitiae” 30, 1994, s. 23. E. Genre w art. Morte e sepolture nella cultura e spiritualitá protestante podaje anglikańskie obrzędy pogrzebowe, gdy przewiduje się kremację: Liturgia per un funerale che prevede la cremazione, s. 734-738. 
kremacja, mówią jedynie o pogrzebie ciała: liturgia słowa w domu zmarłego 28 ; modlitwa „nad ciałem złożonym do trumny i przy nawiedzeniu ciała zmarłego" $^{\prime 29}$. W czasie ostatniego pożegnania formuła poprzedzająca okadzenie przypomina, że „ciało zmarłego było świątynią Ducha Świętego" ${ }^{\prime 30}$. Błogosławiąc na cmentarzu grób, kapłan prosi Boga o uwolnienie od wszystkich grzechów duszy zmarłego, którego „ciało tutaj składamy”, lub aby przyjął do nieba jego duszę, gdy „składamy jego ciało w grobie”"31. Obecnych przy grobie wiernych kapłan wzywa do modlitwy, aby Bóg, „dla którego wszystko żyje, ciało naszego brata/siostry wskrzesił w chwale i powołał go/ją do społeczności Świętych"32. Przytoczone powyżej teksty nie odpowiadają prawdzie znaku, jeśli w trumnie nie ma ciała, lecz urna zawierająca prochy zmarłego.

Problem pogrzebu był tematem Stowarzyszenia Europejskich Sekretarzy Komisji Liturgicznych (22-27 VI 1992) w Berlinie ${ }^{33}$. Zwrócono uwagę na zmiany, jakie dokonały się w ostatnich latach, a dotyczyły przeżywania śmierci, żałoby i pogrzebu. Polegają one na zanikaniu tradycyjnych zachowań, takich jak żałoba $\mathrm{w}$ rodzinie, składanie kondolencji, a nawet brak zainteresowania pogrzebem osób najbliższych. Jako przyczyny takich zachowań wskazano eliminację tematu śmierci z kręgu zainteresowania, jej prywatyzację (occultation et privatisation de la mort) i marginalizację na rzecz dominacji wartości doczesnych. W takiej sytuacji ważnym zadaniem Kościoła jest głoszenie orędzia o zbawczej śmierci Chrystusa i Jego zmartwychwstaniu oraz zachęta do uczestnictwa w pogrzebie z tej racji, że zmarły był członkiem Kościoła i miejscowej wspólnoty wiernych. Dlatego należy przeciwstawiać się tendencji organizowania pogrzebu poza parafią zmarłego, z którą był związany i w której życiu uczestniczył. Chodzi nie tylko o wymagania prawne, ale fakt ten ma także znaczenie symboliczne. W czasie pogrzebu wspólnota Kościoła żegna swojego członka i przekazuje go Kościołowi w niebie ${ }^{34}$. Zauważono także, że istnieje konieczność większego udziału rodziny i wspólnoty w przygotowaniu i liturgii pogrzebu. W związku z tym zaznaczono, że nie należy wszystkiego, co związane jest ze śmiercią i pogrzebem zlecać wyspecjalizowanym przedsiębiorstwom.

Odnośnie do duszpasterzy podkreślono, że ich posługa nie powinna ograniczać się jedynie do samej liturgii pogrzebu w kościele, ale winna obejmować również liturgię (czuwanie) w domu zmarłego i towarzyszenie mu

${ }^{28}$ Obrzędy pogrzebu, nn. 26-38.

${ }^{29}$ Tamże, nr 39.

${ }^{30}$ Tamże, nr 65.

${ }^{31}$ Tamże, nr 70 A i B.

${ }^{32}$ Tamże, nr 71; por. nn. 77; 126; 246.

${ }_{33}$ Association Européenne des Secrétaires Nationaux de Liturgie, Les funérailles en Europe. Proposition pour une pastorale, "Notitiae" 30, 1994, s. 61-69.

${ }^{34}$ Tamże, s. 62-63. 
do grobu na cmentarzu. Podobnie członkowie wspólnoty parafialnej mają do spełnienia własne zadania przed pogrzebem (odwiedziny $\mathrm{w}$ domu żałoby połączone z modlitwą za zmarłego i wyrażenie współczucia rodzinie, pomoc w przygotowaniu pogrzebu), w czasie pogrzebu (wykonywanie czytań i śpiewów, wezwań modlitwy powszechnej, odprowadzenie zmarłego do grobu) i po pogrzebie (kontakt z rodziną zmarłego, modlitwa w rocznicę śmierci i w dzień Wszystkich Wiernych Zmarłych) ${ }^{35}$.

W związku z kremacją stwierdzono, że jeśli rodzina zdecydowała się na spalenie zwłok, należy jej przypomnieć, że stanowi to ostatni etap pożegnania (séparation, comme l'inhumation) i że celebracja liturgii pogrzebowej w kościele przy urnie może odbyć się tylko wyjątkowo. Wyrażono także postulat, aby nowe wydanie rytuału pogrzebu zawierało elementy liturgii przyjęcia urny i jej złożenia w kolumbarium lub na cmentarzu. Rozsypywanie prochów zmarłych zostało uznane za zwyczaj niemający charakteru chrześcijańskiego ( $n^{\prime} a$ aucun caractčre chrétien) i dlatego nie mogą towarzyszyć mu żadne obrzędy ${ }^{36}$.

W ostatnich latach niektóre Konferencje Biskupów otrzymały pozwolenie na doświadczenia i na celebrację liturgiczną przed i po spaleniu ciała. Stolica Apostolska zatwierdziła angielską wersję takiego rytuału ${ }^{37}$. Natomiast biskupi USA otrzymali (21 III 1997) indult pozwalający biskupowi diecezjalnemu na udzielenie zgody, aby przy urnie z prochami sprawować całą liturgię pogrzebową. Przygotowano tam Appendix do Ordo Exsequiarum, który został zatwierdzony przez Kongregację Kultu Bożego (30 VII 1997). Zawarte są w nim teksty oraz refleksja teologiczna krajowej Komisji Liturgicznej o godności ciała ludzkiego, o kremacji i odnośnych obrzędach.

W Italii Komisja Biskupów ds. liturgii w związku z rozpowszechniającym się tam zwyczajem świeckich obrzędów przed kremacją jako naśladowanie pogrzebu kościelnego, które odbywają się w istniejących już na cmentarzach tzw. salach pożegnań (sala del commiato), wydała odnośne zalecenia dla duszpa-

35 Tamże, s. 65.

${ }^{36}$ Tamże, s. 68. W 1993 r. Konferencja Biskupów Japonii zajmowała się rewizją obrzędów pogrzebowych wydanych w 1971 r., aby dostosować je ich mentalności wiernych Kościoła w Japonii. Zob. Revision of Funeral Rites for the Church in Japan, Notitiae 30, 1994, s. 430-438. Obrzędy te w 1993 r. zostały zatwierdzone przez Kongregacje Kultu Bożego na okres 5 lat. W Japonii powszechnie stosuje się kremację. Obrzędy pogrzebu rozpoczynają się od czuwania przy zmarłym i modlitwy połączonej z liturgią słowa. Przewiduje się modlitwy w krematorium (Prayer at the crematory: Prayer after the cremation i Prayer at home). Ponieważ katolicy w Japonii stanowią jedynie 0,3\% ludności i w czasie pogrzebu są często obecni także niechrześcijanie, nie zawsze sprawuje się Eucharystię, a jedynie liturgię słowa Bożego. Duże znaczenie w tradycji japońskiej mają Memorial Days i modlitwy na cmentarzu (Prayer for the mememorial days) w trzeci, siódmy, trzydziesty, czterdziesty dziewiąty lub pięćdziesiąty dzień po śmierci.

${ }^{37}$ Notitiae 30, 1994, s. 23. 
sterzy. Wymienia się $\mathrm{w}$ nich $\mathrm{z}$ dezaprobatą rozsypywanie czy przechowywanie prochów. Takie postępowanie wynika z racji praktycznych i jest konsekwencją kremacji, która jest także wyrazem przekonania o unicestwieniu człowieka i jego całkowitym zlaniu się z kosmosem. W tym sensie wyraża poglądy panteistyczne, prowadzi do likwidacji cmentarzy i całej związanej z nimi tradycji chrześcijańskiej ${ }^{38}$.

Włoskie prawo państwowe z 30 III 2001 r. reguluje zasady postępowania odnoszące się do kremacji oraz rozsypywania prochów zmarłych ${ }^{39}$. Jest ono dozwolone, jeśli następuje zgodnie z wyraźnie wyrażoną wolą zmarłego potwierdzoną przez właściwy urząd cywilny. W innym wypadku oraz gdy dokonuje się w sposób odmienny, niż wyraził to zmarły, podlega karze więzienia od 2 miesięcy do roku i pieniężnej od 5 do 25 milionów lirów. Prawo to określa także, że rozsypania prochów można dokonać tylko w wyznaczonych miejscach: wewnątrz cmentarzy, na otwartych terenach prywatnych, ale jedynie za zgodą ich właścicieli, w morzu, jeziorach i ogólnie dostępnych rzekach. Natomiast zakazane jest na obszarach zamieszkałych. Do rozsypywania prochów upoważnione są następujące osoby: współmałżonek zmarłego, członkowie jego rodziny, osoba wyznaczona w testamencie lub należąca do stowarzyszenia, którego członkiem był zmarły, w razie braku wyżej wymienionych osób odpowiedni przedstawiciel gminy. Jeśli urna z prochami ma być jakiś czas przechowywana, wówczas powinna być zapieczętowana, i zaopatrzona $\mathrm{w}$ dane osobowe zmarłego wraz $\mathrm{z}$ wyrażoną przez niego wolą

\section{DLACZEGO KOŚCIÓł PREFERUJE GROBY I TRADYCYJNY POGRZEB?}

Pogrzebanie ciała w ziemi jest dla chrześcijan nie tylko naśladowaniem pogrzebu Chrystusa, ale także wyraża wiarę w zmartwychwstanie oraz ma znaczenie symboliczne ${ }^{41}$. Jest przekazaniem ciała ziemi, z której człowiek został stworzony przez Boga, i lepiej wyraża okazywany mu szacunek w perspekty-

${ }^{38}$ Bardziej szczegółowe przepisy odnośnie pogrzebu katolickiego po kremacji, kolumbarium oraz przechowywania urn z prochami wydała np. w Hiszpanii diecezja Orviedo. Zob. Rivista Liturgica 93, 2006, s. 776-780.

${ }^{39}$ Disposizioni in materia di cremazione e dispersione delle ceneri. Zob. E. Genre, Morte e sepolture nella cultura e spiritualità protestante, s. 728-729; C. Chenis, Evangelizzare la cremazione per un'icona di Chiesa, tamże, s. 756-780.

${ }^{40}$ Tamże, s. 729.

${ }^{41}$ Mówi o tym modlitwa przy grobie w czasie pogrzebu: „Wszechmogący Boże, Ty przez śmierć krzyżową Twojego Syna, Jezusa Chrystusa, zwyciężyłeś śmierć naszą, a przez Jego spoczynek w grobie i chwalebne zmartwychwstanie uświęciłeś nasze groby i przywróciłeś nam życie nieśmiertelne, wysłuchaj nasze modlitwy za wszystkich, którzy z Chrystusem umarli, zostali pogrzebani i z ufnością oczekują zmartwychwstania". Obrzędy pogrzebu, nr 249. 
wie przyszłego zmartwychwstania. Kościół czyni to w duchu słów św. Pawła „Zasiewa się zniszczalne - powstaje zaś niezniszczalne; sieje się niechwalebne - powstaje chwalebne; sieje się słabe - powstaje moce; zasiewa się ciało zmysłowe - powstaje ciało duchowe. Jeżeli jest ciało ziemskie, powstaje też ciało niebieskie" (1 Kor 15,42-44). Tę wiarę w zmartwychwstanie potwierdza Rytuał pogrzebu Ordo Exsequiarum: „W obrzędach pogrzebowych święta matka Kościół nie tylko poleca Bogu zmarłych, lecz także umacnia nadzieję swoich żyjących dzieci i wyznaje wiarę, że kiedyś wszyscy ochrzczeni zmartwychwstaną z Chrystusem”. Wynika to z natury liturgii pogrzebowej, w której Kościół „obchodzi z wiarą paschalne misterium Chrystusa i modli się, aby ci, którzy przez chrzest zostali wszczepieni w śmierć i zmartwychwstanie Chrystusa, z Nim przeszli przez śmierć do życia"42. W odniesieniu do zmarłych liturgia pogrzebowa jest wyrazem szacunku dla ciała ludzkiego oraz stanowi skuteczną modlitwę wstawienniczą o przyjęcie ich przez Boga, w którego wierzyli i starali się żyć według Jego wskazań. Natomiast dla żyjących jest wezwaniem do wyznania wiary w paschalny charakter śmierci chrześcijanina, a w konsekwencji w zmartwychwstanie; przez to budzi nadzieję i pomaga przeżyć śmierć kogoś bliskiego jako czasowe tylko rozłączenie, pomaga zachować pogodę ducha i broni przed rozpaczą.

Uzasadnienie praktyki grzebania ciała w ziemi opiera się na fakcie stworzenia człowieka z ziemi, do której powraca po śmierci (por. Rdz 2,6; 3,19; Syr 17,1), ale także przypomina pogrzeb Jezusa, który jak ziarno pszenicy wrzucone w ziemię, wydaje owoc obfity (por. J 12,24). Powszechnie wiadomo, że spotkania przy grobach tych, którzy już odeszli z tego świata, mają także znaczenie dla podtrzymywania rodzinnych, przyjacielskich i narodowych więzi. Cmentarze z grobami zmarłych i stojące na nich krzyże przypominają żyjącym o przemijaniu ziemskiego życia, o wierze w życie wieczne i zmartwychwstanie z Chrystusem. Prawdę tę dobrze wyraża modlitwa błogosławieństwa nagrobnego krzyża: „Panie Jezu Chryste, Ty własną śmiercią zwyciężyłeś śmierć naszą, a przez swoje zmartwychwstanie przywróciłeś nam życie, pobłogosław ten krzyż, który stawiamy na chrześcijańskim grobie, aby ciało pod nim złożone wskrzesił do życia w chwale"43. Cmentarze są także miejscem publicznej i prywatnej modlitwy Kościoła za zmarłych ${ }^{44}$. Groby są nie tylko znakiem pamięci

42 Tamze, s. 8 i nr 1.

${ }^{43}$ Tamże, nr 255.

${ }^{44} \mathrm{O}$ potrzebie istnienia cmentarzy świadczy powstająca praktyka tworzenia wirtualnych cmentarzy w Internecie. Np. według informacji KAI z 26 XI 2007 r. „Od początku 2008 r. ruszy w Internecie pierwszy w Szwajcarii wirtualny cmentarz. Na stronie www.hommages.ch za specjalną opłatą bliscy osoby zmarłej, a także inne osoby, będą mogli zamieszczać teksty, fotografie i nagrania, w których wspominają zmarłego. Już teraz na stronie znajdują się informacje tematycznie związane z problemem umierania i śmierci. Zamieszczona jest też 
o zmarłych, ale wyrażają związek z poprzednimi pokoleniami zarówno w wymiarze rodzinnym, jak i narodowym. W taki sposób należy patrzeć na groby swoich bliskich, ale także tych, którzy walczyli i oddali życie za Ojczyznę lub w inny sposób przyczynili się do rozwoju jej duchowej i materialnej kultury.

O ważnej funkcji, jaką pełni chrześcijański cmentarz świadczy również to, że Kościół przewiduje jego specjalne błogosławieństwo i zalicza do miejsc świętych, na których umieszcza się krzyż Chrystusa jako „znak nadziei zmartwychwstania dla wszystkich ludzi". Dlatego chrześcijanie grzebią tam swoich zmarłych i "otaczają szacunkiem nie tylko ciała swoich braci w wierze, lecz także tych, z którymi są związani tą samą ludzką naturą. Chrystus bowiem na krzyżu wszystkich ludzi odkupił i za wszystkich przelał swoją Krew"45. W modlitwie błogosławieństwa cmentarza zawarta jest prośba Kościoła pielgrzymującego, aby cmentarz jako „miejsce przygotowane do grzebania ciał ludzkich, przypominał o przyszłym życiu w Chrystusie, który upodobni nasze ciało podległe zniszczeniu do swojego ciała uwielbionego"46. Właściwa modlitwa błogosławieństwa nawiązuje do postanowienia Bożego, „aby śmiertelne ciało człowieka, ulepione z prochu ziemi, wracało do ziemi". W tej modlitwie Kościół odwołuje się do grzebania zmarłych w Starym Testamencie, do złożenia w grobie Ciała Jego Syna, „aby z niego powstał jako zwycięzca śmierci i dał nam rękojmię przyszłego zmartwychwstania”. Cmentarz i „ziemia przeznaczona dla grzebania ludzkich ciał" ma być miejscem spoczynku i nadziei, a spoczywające w niej ciała zmarłych „powstaną nieśmiertelne w dniu chwalebnego przyjścia Syna Bożego". Za tych, którzy zasnęli w Chrystusie, modlą się żyjący i przez to umacniają się $\mathrm{w}$ nadziei na wieczną nagrodę ${ }^{47}$.

Coraz bardziej powszechna praktyka kremacji ciał zmarłych, chociaż jest dopuszczalna przez Kościół, nie powinna zastępować praktykowanego od wieków zwyczaju grzebania zmarłych chrześcijan. Tam, gdzie jest to możliwe, należy zachować tradycyjny pogrzeb. Nie wydaje się również wskazane zastępowanie tradycyjnych cmentarzy z grobami przez rodzaj budowli z pomieszczeniami na urny z prochami (kolumbarium). Dlatego tak należy formować nowe pokolenie przez ewangelizację, aby zachować kulturę i tradycję chrześcijańską odnośnie do grzebania zmarłych.

większość nekrologów opublikowanych w ciągu ostatnich sześciu miesięcy na łamach prasy regionów Genewy i Lozanny. Na bezpłatną publikację tych nekrologów musieli wyrazić zgodę członkowie rodzin zmarłych. [...] praktycznie każdy może jednym kliknięciem myszką wyrazić swoje współczucie bliskim osoby zmarłej".

${ }^{45}$ Obrzędy btogostawieństw, Katowice 1994, nr 1115.

${ }^{46}$ Tamże, nr 1122.

${ }^{47}$ Tamże, nr 1129. Należy nadal podtrzymywać polską tradycję polegającą na pielęgnowaniu grobów nie tylko swoich bliskich, ale także troskę o inne groby, nawet osób nieznanych (por. groby nieznanego żołnierza), odwiedzania ich i modlitwy za zmarłych na cmentarzu. 
Jeśli zachodzi konieczność sprawowania liturgii pogrzebowej po spopieleniu ciała zmarłego odprawia się za niego Mszę św. w kościele lub w kaplicy cmentarnej według formularza Mszy pogrzebowej, a następnie urnę z prochami składa się w wyznaczonym do tego miejscu. Zanim w rytuale pogrzebu zostaną przygotowane teksty modlitw uwzględniające, że w urnie są prochy, a nie ciało zmarłego, wydaje się, że celebrans liturgii pogrzebowej może tak dostosować niektóre teksty, aby odpowiadały tej sytuacji. Natomiast sprzeczne z wiarą i tradycją chrześcijańską, i dlatego niedopuszczalne, jest rozrzucanie gdziekolwiek prochów zmarłych. Każdy zmarły wierny, poza wypadkami szczególnymi, ma prawo do pogrzebu kościelnego oraz do grobu, na którym będzie krzyż - znak umarłego i zmartwychwstałego Chrystusa.

\section{IL FUNERALE CATTOLICO DOPO LA CREMAZIONE DEL CORPO UMANO}

\section{RIASSUNTO}

$\mathrm{L}^{\prime}$ autore prende in considerazione il problema molto attuale nella Chiesa di oggi, cioè il funerale cattolico dopo la cremazione. Dopo aver parlato della dignità del corpo umano dopo la morte nella luce della bibbia lui presenta il comportamento della Chiesa cattolica di fronte alla cremazione del corpo umano. Poì spiega come si deve fare la funzione funerale dopo la cremazione e perchè la Chiesa preferisce sempre le tombe e funerali tradizionali. 